\title{
Greenhouse Gas Emissions: Contributions Made by Football Clubs in England
}

\author{
Adekunle Dosumu*, Ian Colbeck, Rachel Bragg \\ School of Biological Sciences, Wivenhoe Park, University of Essex, Colchester, UK \\ Email: aadosu@essex.ac.uk
}

Received 19 July 2014; revised 16 August 2014; accepted 12 September 2014

Copyright (C) 2014 by authors and Scientific Research Publishing Inc.

This work is licensed under the Creative Commons Attribution International License (CC BY). http://creativecommons.org/licenses/by/4.0/

CC) (i) Open Access

\begin{abstract}
Greenhouse gas (GHG) emission from waste is a major environmental problem. Globally, the waste management sector contributes an estimated $5 \%$ of the total anthropogenic GHG emissions. This paper estimates GHG emissions from football clubs in the England, where football is the highest profile and most popular sport, with large numbers of spectators and significant quantities of waste being produced. Football clubs should be more committed to reducing their GHG emissions by improving their waste management. The amount of GHG emitted from eight football tiers in England is assessed through methods including interviews, observations and questionnaires. The results reveal that in the 2012/13-football season, over 9 million spectators watched football in the lower leagues, with mean waste per spectator of $3.27 \mathrm{~kg} .30,146,000 \mathrm{~kg}$ of waste was generated at the 8 football tiers, and the amount of waste sent to the landfill was about $74,000,000 \mathrm{~kg}$, which resulted in GHG emissions of approximately $2,100,000 \mathrm{~kg} \mathrm{CO}_{2} \mathrm{e}$. The implications for better waste management at football leagues are outlined.
\end{abstract}

\section{Keywords}

Football, Spectators, Waste, Emissions

\section{Introduction}

The world's population has already exceeded seven billion and is still growing [1]. Waste generation, is directly related to population density, and is responsible for greenhouse gas (GHG) emissions at landfill, which has negative environmental impact. Directive 2008/98/EC Article 3 (1) defined waste as any object or substance which a person discards or is required to discard or intends to discard [2]. Increased solid waste generation is attributed to industrialisation, globalization and rapid economic development. At a global level, the waste management

"Corresponding author.

How to cite this paper: Dosumu, A., Colbeck, I. and Bragg, R. (2014) Greenhouse Gas Emissions: Contributions Made by Football Clubs in England. Atmospheric and Climate Sciences, 4, 642-652. http://dx.doi.org/10.4236/acs.2014.44057 
sector contributed an estimated 5\% of the total anthropogenic emissions in 2012 [3]. In light of this development, the waste sector can now be an emission saver instead of an emission generator by implementing sustainable waste management plans. Sport is now part of the society because millions of spectators watch games on a regular basis [4]. But as one of many human activities, wastes produce GHG emissions at landfills, which has become a global concern that needs to be addressed.

\subsection{Waste Management}

The collection, recycling, treatment and disposal of increasing quantities of solid waste remain a major challenge. UNEP reported that in 2012, around 11.2 billion tonnes of waste was collected globally [5]; emissions from commercial and industrial waste landfill generated $2.3 \mathrm{Mt} \mathrm{CO}_{2} \mathrm{e}$ and the decomposition of organic materials at the landfill contributes around $5 \%$ of all global greenhouse gas emissions [6]. In the UK, the waste sector is responsible for 17 million tonnes of carbon emissions a year [6] [7]. During 2013, in England alone, approximately 177 million tonnes of waste could be attributed to poor use of resources, having huge economic impacts to both individuals and businesses [8]. The issue of reducing, reusing and recycling waste rather than dumping it in landfill therefore, reduces these environmental impacts.

A holistic approach to waste management has positive consequences for greenhouse gas emissions from various sources [4]. Waste can be classified by its source and by its properties as shown in Figure 1 [9]. Waste generated from sport is classified under commercial waste, which according to Chartered Institute of Waste Management is defined as waste from premises used exclusively or primarily for the purposes of a business or for the purpose of entertainment, education, recreation or sport [10].

To effectively manage waste, the waste hierarchy should be applied. This is the classification of waste management options in order of their environmental impact, such as: reduction, reuse, recycle and recovery [11]-[14]. The waste hierarchy has five stages: prevention, preparing for re-use; recycling; other recovery e.g. energy recovery; and disposal [2] [14]-[17].

The main purpose of the waste hierarchy is to extract the maximum practical benefits from products and to generate the least amount of waste as revealed in Figure 2. However, there are some wastes for which the management options are limited and the best environmental option with the least impact lies towards the bottom of the hierarchy [18] [19]. In deciding the most appropriate waste disposal route, both economic and environmental benefits need to be considered.

\subsection{Waste and Sport}

When considering materials used by spectators and participants engaging in sport, it is evident that resources from water, energy and other consumables are required. Inevitably, sport leads to the generation of waste and pollution, which releases emissions of greenhouse gases [20] [21]. There is now a growing recognition that waste is one of the major environmental problems associated with mega sporting events such as the World Cup, the Olympic Games, and Football Association (FA) Cup final. For example, the 2004 FA Cup Final held at Millennium Stadiumin Cardiff resulted in 59 tonnes of waste, which is equivalent to $0.81 \mathrm{~kg} / \mathrm{spectator}$ [22]. The 2012 FA Cup Final held in Wembley Stadium resulted in 24 tonnes of waste (of which 25\% was sent to the landfill), reflecting $0.27 \mathrm{~kg} /$ spectator [23]. The 2013 FA Cup Final resulted in slightly less waste (21.5 tonnes with $18 \%$ sent to landfill) with the equivalent of $0.25 \mathrm{~kg} / \mathrm{spectator}$ [24].

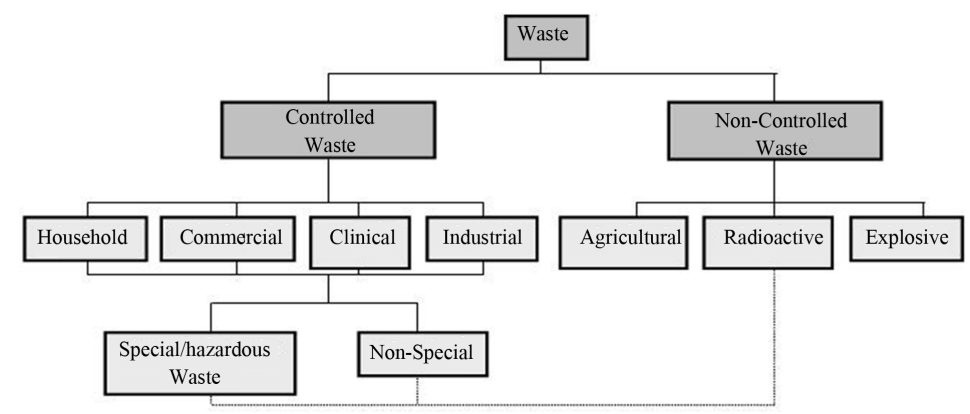

Figure 1. Waste classification framework. Source: (DEFRA 2011). 


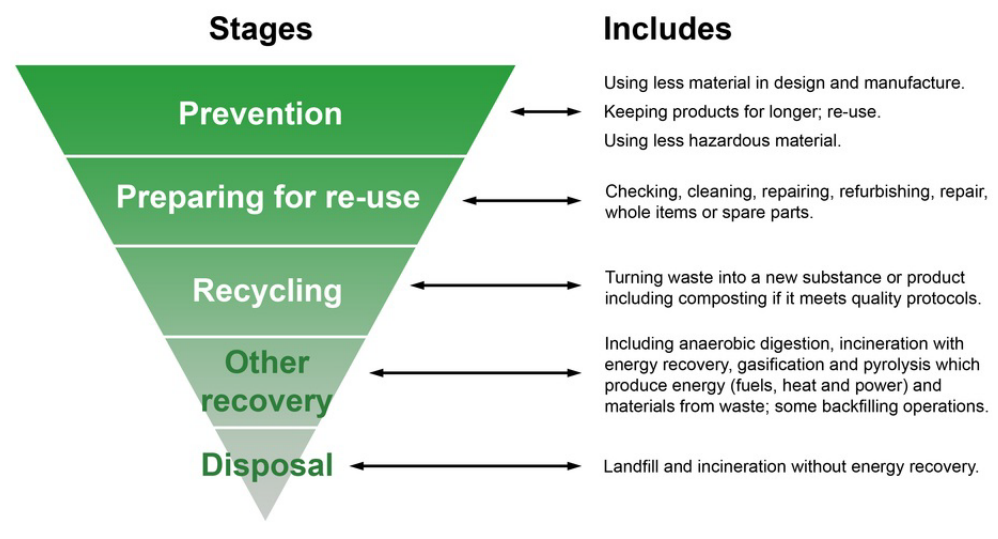

Figure 2. Waste hierarchy in UK. Source: (DEFRA 2007).

In regards to World Cups, the South African World Cup in 2010 generated waste of $1.8 \mathrm{~kg} / \mathrm{spectator}$ [25] which is 5 times more than the waste generated at the 2006 World Cup, due to the quantity of waste generated and lack of proper waste management practice. The Olympics in Beijing 2008 produced about 48,000,000 kg of waste [26] with 6.8 million spectators resulting in $7.06 \mathrm{~kg} / \mathrm{spectator}$. However, the London 2012 Olympic games recorded about 10,000,000 kg of waste [27] with 11 million spectators, resulting in $0.91 \mathrm{~kg} / \mathrm{spectator}$ [28]. This shows that sports generate a tremendous amount of waste but in different proportion depending on the sporting event.

Therefore, the sports sector has a major part to play both in cutting waste resulting from events and also in emission reduction from waste sent to landfill. Moreover, the overall climatic impact of the waste management system depends on proper accounting for waste generated, recycled and landfilled. At football league levels, the magnitude of these emissions are difficult to determine due to poor data collection on the proportions of waste generated, recycled and landfilled. The aim of this study is to estimate the amount of waste and greenhouse gas emitted from landfill waste over a range of football league tiers in England.

Within England, football is played at different levels, with eleven tiers making up the English pyramid system. The Premier League is the top tier followed by the Championship and Football Leagues One and Two. Below these is the National League System, which stretches from the Football Conference Premier Division through to County Leagues [29]. A total of 59 leagues incorporating 84 divisions across the country provide a feeder system through to the Football League. The lower leagues, consisting of more than 900 clubs, cover smaller geographical areas. Going down through the levels in the National League System the number of spectators at each game drops but the number of games increases, and when aggregated nationally are on par with numbers for the Premier League [29] [30].

Football clubs are slower than other industries to adopt environmental management practices and develop Corporate Social Responsibility (CSR) strategies. Although they are addressing Environmental sustainability, most do so in a non-strategic way with no formalized management systems. At higher football levels (Tiers 1 and 2) environmental considerations are sometimes packaged with a club's corporate social responsibility programme. For example Arsenal FC has a Waste Recycling Center, which recycles 10 tonnes of cardboard and plastic, and 1.5 tons of glass every month [31]. Manchester City FC has significantly improved their waste disposal over the past seven years, to the extent that none of their waste goes to landfill [32]. Similarly Manchester United FC has achieved 100\% diversion of waste from landfill and has reduced waste generated yearly [33].

Previous studies on mega sporting events encourage actions that promote environmental sustainability to be taken [34], and in England, the contribution of football clubs to climate change are increasingly a focus of discussion and debate [35]. Although, clubs at the Premier League and Championship have started to reduce their environmental impact, but limited step is taken by the clubs in the non-league levels to reduce their environmental impacts [36]. Currently there is scarcity of studies in the literature on the environmental impact of lower level football clubs on day-to-day basis. As such, this paper will focus on waste generation and GHG emissions from waste sent to landfill among football clubs within eight leagues, from tier 3 to tier 10 in England. The quantity of waste and GHG emissions from these levels will also be extrapolated to the National level. 


\section{Methodology}

A survey research method was adopted for this study in order to examine waste management practices and then to calculate the estimated landfill waste GHG emissions from eight football tiers in England (Tier 3 - Tier 10) as shown in Table 1. In addition to interviews and physical observations, structured questionnaires were also used to collect data from football clubs and waste contractors. The football tiers, clubs, leagues and waste contractors selected are shown in Table 2.

In collaboration with Essex FA one club was selected from each tier from 3 to 10 to be representative of clubs at that tier. Due to variations in the clubs at tier 5 another 2 clubs were selected to account for the variation in tier composition. Site surveys were carried out at the study locations as to observe and examine the current practices of waste management. An observational checklist was used to record the findings from the surveys and questionnaires were used to identify the level of knowledge and awareness on football waste management among respondents.

The questionnaire was designed such that data could be collected on not only annual waste generated by football clubs at each level, but also on waste policy, waste contractor, types of waste generated, types and size of waste containers, frequency of waste collection, percentage waste diverted from the landfill and percentage

Table 1. The football tier in England.

\begin{tabular}{ccc}
\hline Football Tier & League/Non-League Name & Number of Clubs \\
\hline 1 & Premier League & 20 \\
2 & Football League Championship & 24 \\
3 & Football League One & 24 \\
4 & Football League Two & 24 \\
5 & Conference Premier & 44 \\
6 & Conference North \& South & 66 \\
7 & Northern, Southern \& Isthmian League Premier Division & 123 \\
9 & Northern, Southern \& Isthmian League Lower Division & 291 \\
11 & Top tier of 14 regionally based leagues & 285 \\
\hline
\end{tabular}

Note. Football tiers was adapted from Football Insights 2007 [37] and Football Pyramid 2012 [30].

Table 2. Football tiers, leagues, clubs and their waste contractors.

\begin{tabular}{|c|c|c|c|}
\hline Football Tier & League & Football Club & Waste Collector/Contractor \\
\hline Tier 3 & League 1 & Colchester United & Colchester Skip Hire Environmental Ltd \\
\hline Tier 4 & League 2 & Southend United & Veolia Environmental Services \\
\hline \multirow{3}{*}{ Tier 5} & Conference Premier & Braintree Town & Braintree District Council \\
\hline & Conference Premier & Dartford & Veolia Environmental Services \\
\hline & Conference Premier & Cambridge United & Mick George Limited \\
\hline Tier 6 & Conference South & Chelmsford City & Chelmsford City Council \\
\hline Tier 7 & Isthmian Premier & East Thurrock & Veolia Environmental Services \\
\hline Tier 8 & Isthmian Division One North & Aveley & Ahern Waste Limited \\
\hline Tier 9 & Thurlow Nunn Premier Division & FC Clacton & Veolia Environmental Services \\
\hline Tier 10 & Essex Senior League & Barking & Veolia Environmental Services \\
\hline
\end{tabular}


landfill waste. Face to face interviews were conducted with respective football clubs waste contractors to verify the information given by each club regarding their waste management. Structured interviews were conducted to obtain information on waste management. Information obtained included amount of waste collected, the type and size of waste container used, frequency of collections and proportion of waste recycled.

Waste per spectator was calculated by dividing the annual waste at the representative club at the league level by the annual number of spectators at that club. Then the resulting wastes per spectator figures were used to estimate annual waste generated at that football tier by multiplying waste per spectator by annual spectators at that football tier and the result extrapolated to national level. The GHG emissions were calculated by multiplying the annual waste landfilled at each football tier, by using DEFRA's conversion factors of $290 \mathrm{~kg} \mathrm{CO}_{2} / 1000 \mathrm{~kg}$ (commonly used in calculating emissions from municipal waste) [38].

Greenhouse gas emissions are categorized into three scopes by the most widely used international accounting tool, the GHG Protocol [3] [38]. Scopes 1 and 2 cover direct emissions sources while scope 3 emissions cover all indirect emissions due to the activities of an organization such as waste disposal [39]-[41]. The $\mathrm{CO}_{2} \mathrm{e}$ emissions were determined by using extrapolated annual waste at each football tier using the following formula:

$$
\begin{aligned}
& \mathrm{CO}_{2} \mathrm{e} \text { emissions from waste from football tiers } \\
& \left.=\sum(\text { Total mass of waste landfill (tonnes })\right) \times \text { emission factor of waste landfill }\left(\mathrm{kg} \mathrm{CO}_{2} \mathrm{e} / \text { tonnes }\right) .
\end{aligned}
$$

\section{Results}

A total of ten questionnaires were completed by football club representatives as well as ten waste contractors (Table 2). Additionally, interviews and observations took place at each club. Total waste generated at football clubs during 2012/13 season ranged from about 2 tonnes to 345 tonnes. Annual number of spectators at the club level ranged from 931 spectators to 114,494. The waste per spectator ranged from $1.82 \mathrm{~kg} / \mathrm{spectator}$ to 6.81 $\mathrm{kg} / \mathrm{spectator}$; mean waste per spectator was $3.27 \mathrm{~kg}$. The total number of spectators during 2012/13 season was $9,162,067$.

\subsection{Waste and Emissions from Football League Level}

The result of waste per spectator, annual waste, and annual attendance at football clubs and tiers for 2012/13 football season is given in Table 3.

\subsection{Percentage Landfill and Diverted Waste from Football Tier}

The percentage of waste landfilled and diverted from landfill between the football tiers during 2012/13 season is shown in Figure 3. Tier 3 sent the least proportion of waste to the landfill (11\%), while tier 6 sent the highest proportion of waste to landfill (53\%).

\subsection{Extrapolated Result}

Table 4 shows the waste per spectator, annual attendance and extrapolated annual waste at the football tiers. Number of spectators ranged from 268,470 to $3,473,154$. This resulted in total annual waste of approximately 30,146 tonnes. At the league level (tiers 3 and 4) the annual waste was 19,367 tonnes, the mean was 9,683 tonnes compared to non-league (tiers 5 to 10) with annual waste of 10,779 tonnes and a mean of 1,797 tonnes. The waste generated at the league level was almost double the waste generated at the non-league levels as shown in Table 4.

\subsection{Extrapolated Greenhouse Gas Emissions at Football Tiers}

The extrapolated greenhouse gas emissions from waste sent to landfill for tiers 3 to 10 was 2,149,529 $\left(\mathrm{kg} \mathrm{CO}_{2} \mathrm{e}\right)$. The GHG emissions ranged from 35,453 $\left(\mathrm{kg} \mathrm{CO}_{2} \mathrm{e}\right)$ to 564,386 $\left(\mathrm{kg} \mathrm{CO}_{2} \mathrm{e}\right)$. The highest GHG emission was from Tier 6 as shown in Figure 4. The league level (Tier 3 \& 4) emitted 914,796 $\left(\mathrm{kg} \mathrm{CO}_{2} \mathrm{e}\right)$ while the non-league emitted 1,234,733 $\left(\mathrm{kg} \mathrm{CO}_{2} \mathrm{e}\right)$ as shown in Figure 5. The result shows that GHG emissions varied across the football tier.

Comparing, the greenhouse gas emission between the league and non-league levels, this study revealed that 
Table 3. Annual attendance, annual waste and waste per spectator during 2012/13-football season.

\begin{tabular}{|c|c|c|c|c|}
\hline Football Tier & $\begin{array}{c}\text { Selected Football Club } \\
\text { (representative of Football Tier) }\end{array}$ & $\begin{array}{l}\text { Annual Waste } \\
\text { (tonnes) }\end{array}$ & Annual Attendance & $\begin{array}{c}\text { Waste per Spectator } \\
(\mathrm{kg})\end{array}$ \\
\hline Tier 3 & Colchester United & 281.69 & 81,179 & 3.47 \\
\hline Tier 4 & Southend United & 345.77 & 114,494 & 3.02 \\
\hline Tier 5 & 3 clubs $^{*}$ & 97.50 & 38,376 & 2.54 \\
\hline Tier 6 & Chelmsford City & 37.90 & 5,566 & 6.81 \\
\hline Tier 7 & East Thurrock & 8.31 & 3,596 & 2.31 \\
\hline Tier 8 & Aveley & 9.39 & 2,241 & 4.19 \\
\hline Tier 9 & FC Clacton & 4.30 & 2,160 & 1.99 \\
\hline Tier 10 & Barking & 1.69 & 931 & 1.82 \\
\hline
\end{tabular}

Waste per spectator = Annual club waste divided by annual attendance at the club. ${ }^{*}$ Braintree Town FC, Dartford FC and Cambridge United FC with average annual waste, annual attendance and waste per spectator.

Table 4. Football Tier, waste per spectator, total annual attendance and total annual waste 2012/13 season.

\begin{tabular}{cccc}
\hline Football Tier & Waste per Spectator $(\mathrm{kg})$ & Annual Attendance & Annual Waste (tonnes) \\
\hline${ }^{*}$ Tier 3 & 3.47 & $3,473,154$ & 12,052 \\
${ }^{*}$ Tier 4 & 3.02 & $2,422,218$ & 7,315 \\
${ }^{* * *}$ Tier 5 & 2.54 & $1,041,886$ & 2,646 \\
${ }^{* *}$ Tier 6 & 6.81 & 539,217 & 3,672 \\
${ }^{* * *}$ Tier 7 & 2.31 & 413,765 & 956 \\
${ }^{* * *}$ Tier 8 & 4.19 & 463,398 & 1,942 \\
${ }^{* *}$ Tier 9 & 1.99 & 539,959 & 1,075 \\
${ }^{* * *}$ Tier 10 & 1.82 & 268,470 & 489 \\
\hline
\end{tabular}

Source. Annual league attendance for 2012/13 football season for tier 3 to tier 10 [42]-[44]. ${ }^{*}$ League level and ${ }^{* *}$ Non League level. Football Tier Annual waste $=$ waste per spectator $\times$ annual attendance .

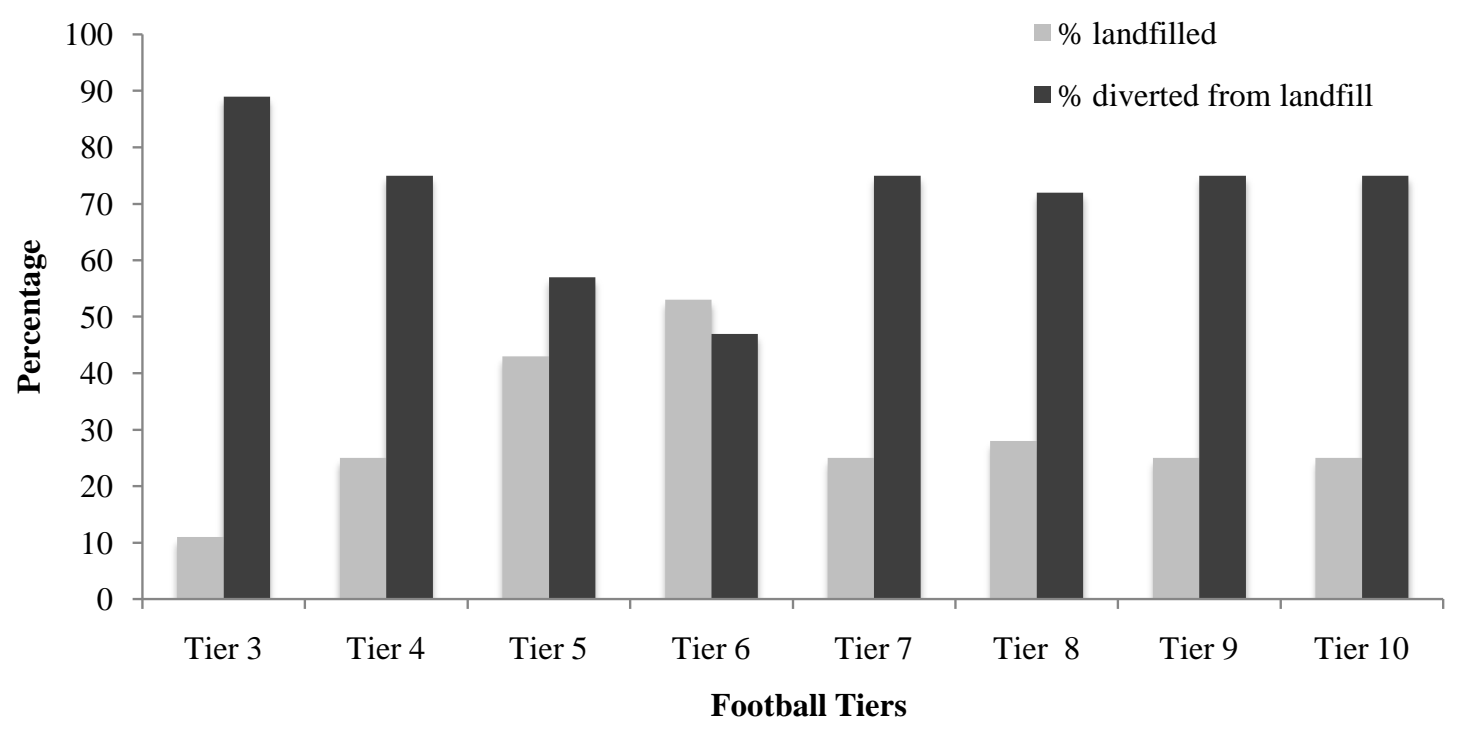

Figure 3. Proportion of waste sent to and diverted from landfill at football tiers. 


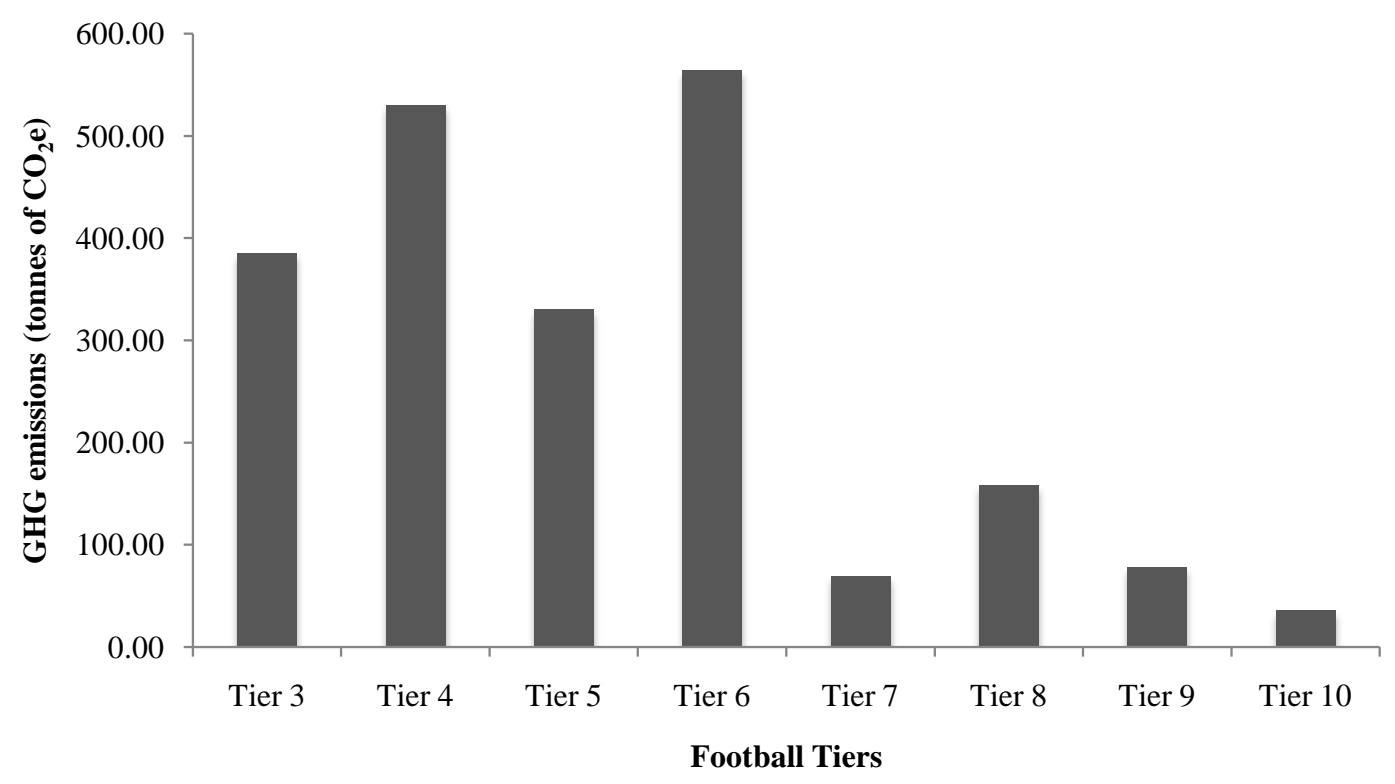

Figure 4. GHG Emissions from waste sent to landfill at Football Tiers.

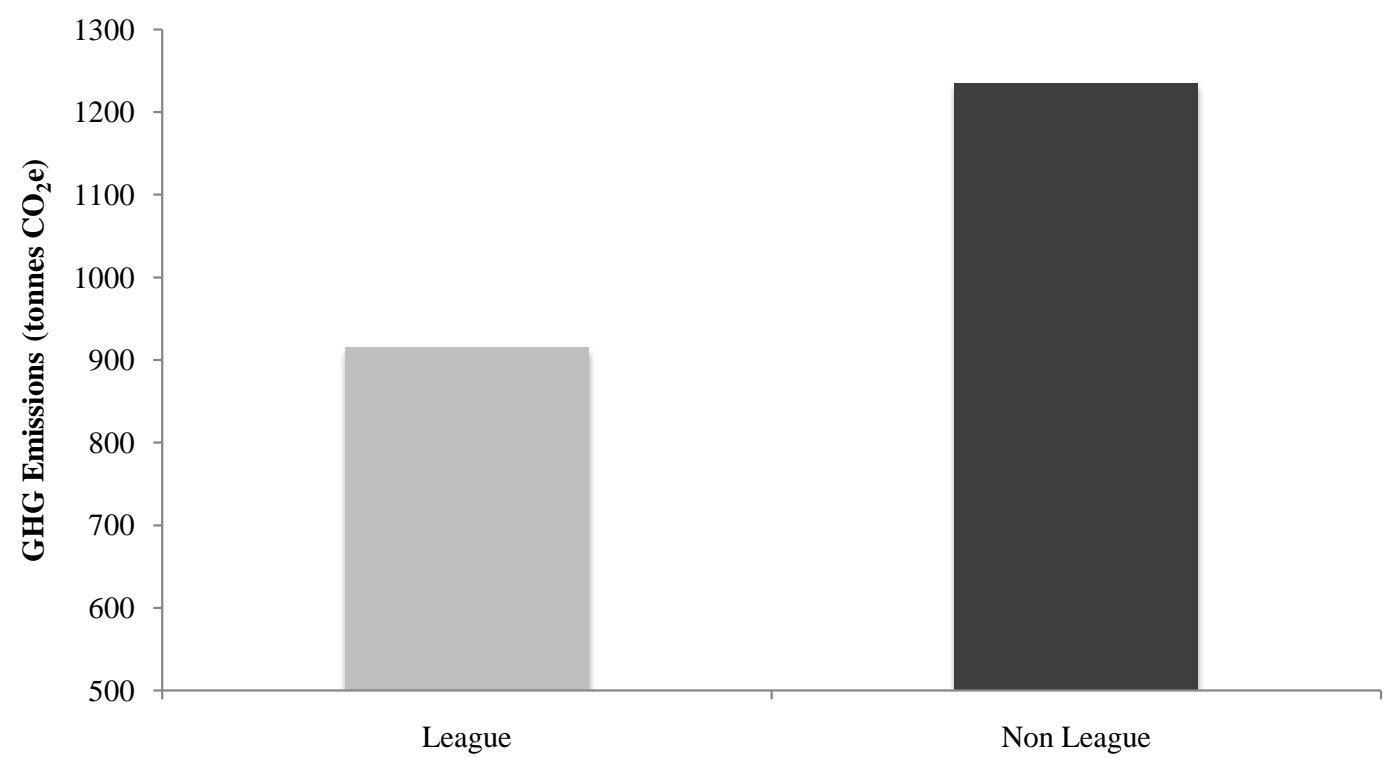

Figure 5. GHG Emissions from waste sent to landfill at football league and non-League.

GHG emissions from the non-league level was higher than that of the league level. This suggests that the GHG contribution of non-league is also significant as shown in Figure 5.

\section{Discussion}

This study shows that football spectators generated large quantities of waste over a season. Table 1 shows that the number of spectators at each game drops down as you descend the football tiers. This drop in spectator numbers is particularly evident at non-league level where the number of clubs and games is much more than in the upper tiers. Nonetheless when aggregated nationally the resultant figures are on par with that of the Premier League [30]. Table 3 reveals; the mean waste per spectator at the league level was $3.24 \mathrm{~kg}$ per spectator, which was similar to $3.27 \mathrm{~kg}$ per spectator at the non-league level. The mean waste generated by each spectator for all the football tiers was $3.27 \mathrm{~kg}$ per spectator, which is more than 10 times the waste produced by each spectator at 
2012 and 2013 FA cup final of $0.27 \mathrm{~kg}$ per spectator and $0.25 \mathrm{~kg}$ per spectator respectively [23] [24]. Table 3 also shows the annual waste generated at Tiers 3 to 10 of the Football League. The resultant figure of over $30,146,000 \mathrm{~kg}$ is about times 3 the waste generated at the 2012 London Olympic games [27]. Figure 3, shows that almost $30 \%$ of the waste generated at the 8 football tiers was sent to landfill, thereby resulting in GHG emissions of 2,149,529 $\mathrm{kg} \mathrm{CO}$ e. The percentage of waste sent to landfill (29\%) as shown in Figure 3 was higher than the waste sent to landfill at FA Cup Final in 2012 (25\%) and in 2013 (18\%). The recycling rate from this study is about the same as household waste recycling rate in England [45]. The extrapolated GHG emissions of 8 football tiers represented less than 1\% of UK GHG emissions. The GHG emission from the non-league level was higher than the league level as compared in Figure 5.

This study is the first to evaluate waste management practices among 8 football tiers in England. One of the factors that made the football clubs to act at reducing their GHG emissions was due to the increase in the landfill tax, which is the key policy driver employed under the 1999 EU Landfill Directive, which required a 50\% reduction in biodegradable municipal waste landfilled in the UK by 2013 [46] [47]. The landfill tax has increased from its initial rate of £7/tonne in 1996 to £80/tonne in 2014 [48]. To further complement the impact of the landfill tax, football clubs and other sectors should encourage waste reduction, reusing and recycling, in order to reduce waste sent to landfill. Football clubs should encourage composting their organic waste to reduce GHG emissions.

League and non-league football clubs need to start using better data collection methods. A good example would be the Pay-By Weight system to manage their waste effectively and monitor their performance [49]. Moreover, this study shows that there is an obvious desire among football clubs at various league levels to improve their performance, with many now employing professional services to oversee their waste operations. In this study $70 \%$ of football clubs sampled employ the services of private waste contractor to manage their waste.

Sports organizers in general and football clubs in particular should be at the forefront of better waste management with the result that GHG emissions are reduced. Since the worldwide popularity of football continues to grow, the industry can contribute positively to the environment by being responsible for the environmental management of all aspects of the game [50]. Corporate Social Responsibility is relatively a new concept in sports management. As a result of the industrialisation of football, clubs, national federations and continental confederations have four responsibilities under CSR. These are economic responsibility, legal responsibility, ethical responsibility and lastly discretionary responsibility [51]-[57] Sport, including football, has greater effects than other businesses in providing support and inspiration in such areas as education, health and wellness, environment, art and culture [58].

Football clubs do face issues of sustainability due to their operations [59]. Akansel reported that Besiktas football club through the "Be Green initiative" enlightened and encouraged their supporters to be more environmentally friendly. The club started with their immediate environment, Inonu Stadium by installing recycling bins around the stadium and used energy efficient light bulbs and recycled napkins [50]. Football clubs are slower than other industries to adopt environmental management practices and develop CSR strategies because of their lack of positive attitude. Although they are addressing environmental sustainability, most do so in a nonstrategic way with no formalized management systems. Although many corporate organizations have moved to a wider social audit of their performance that includes triple bottom line reporting of their economic, environmental and social performance. Football clubs have not yet moved in this direction [59].

\section{Limitations of the Study}

One of the key limitations of the study was the fact that waste data collection was carried out at one football club per football tier. Future research could be strengthened by incorporating more clubs at each football tier and with more available resources.

\section{Conclusions}

The main aim of this study was to estimate the amount of waste produced at the various football tiers in England. This study has presented, for the first time, using waste generation data and GHG emissions at football tiers to extrapolate to national level the quantity of waste and GHG emissions from football in England. During the 2012/13 football season, approximately 9 million spectators watched football, with average waste per spectator of $3.27 \mathrm{~kg}$. The amount of waste generated at the 8 football tiers was approximately 30,146 tonnes. Waste sent 
to landfill was about 7,412 tonnes, which resulted in GHG emissions of 2,149,529 $\mathrm{kg} \mathrm{CO}_{2} \mathrm{e}$, accounting for less than $1 \%$ of UK GHG emissions. The GHG emission at the league level was 914,796 $\left(\mathrm{kg} \mathrm{CO}_{2} \mathrm{e}\right)$ which was less than emissions at the non-league level 1,234,733 $\left(\mathrm{kg} \mathrm{CO}_{2} \mathrm{e}\right)$.

Diverting waste from landfill appears to be the best option to adopt across football tiers to reduce GHG emissions. Hence, football clubs have a lot to do to reduce their environmental impact. They have great opportunity to educate spectators to practice waste reduction and maximize waste recycling.

\section{Acknowledgements}

The authors thank Essex Football Association for their support and the management of the following clubs for granting permission to conduct this study at their clubs: Colchester United FC, Southend United FC, Braintree Town FC, Dartford FC, Cambridge United FC, Chelmsford, FC, East Thurrock FC, Thurrock FC, FC Clacton and Barking FC.

\section{References}

[1] Cleland, J. (2013) World Population Growth; Past, Present and Future. Environmental and Resource Economics, 55, 543-554. http://dx.doi.org/10.1007/s10640-013-9675-6

[2] European Commission (2008) Directive 2008/98/EC on Waste. http://ec.europa.eu/environment/waste/framework/pdf/guidance_doc.pdf

[3] United Nations Environment Programme (2012) The Greenhouse Gas Protocol. http://www.unep.org/sbci/pdfs/Paris-GHG protocol.pdf

[4] United Nations Environment Programme (2012) Waste and Climate Change: Global Trends and Strategy Framework. http://www.unep.org/ietc/Portals/136/Publications/Waste\%20Management/Waste\&ClimateChange.pdf

[5] United Nations Environmental Programme (2013) Climate Change Mitigation. http://www.unep.org/climatechange/mitigation/Waste/tabid/104349

[6] Carbon Trust (2013) Carbon Trust to Take on Waste. http://www.carbontrust.com/about-us/press/2013/07/carbon-trust-to-take-on-waste

[7] Public Sector (2013) Public Sector-News—Latest News-New Waste Standard Introduced. http://www.publicsector.net/news/article.asp?CategoryId=2\&ArticleId=16492

[8] DEFRA. Department for Environment, Food \& Rural Affairs (2013) Reducing and Managing Waste. http://www.gov.uk/government/policies/reducing-and-managing-waste

[9] DEFRA. Department for Environment, Food \& Rural AffairsEFRA (2011) Guidance on Applying the Waste Hierachy. http://www.gov.uk/government/uploads/system/uploads/attachment_data/file/69403/pb13530-waste-hierarchy-guidanc e.pdf

[10] Chartered Institute of Waste Management (2010) Explanation of Waste. http://www.iwm.co.uk/pma/1384

[11] De Brito, M.P. and Dekker, R. (2004) A Framework for Reverse Logistics. Springer, Berlin.

[12] Demirbas, A. (2011) Waste Management, Waste Resource Facilities and Waste Conversion Processes. Energy Conversion and Management, 52, 1280-1287. http://dx.doi.org/10.1016/j.enconman.2010.09.025

[13] Seadon, J.K. (2010) Sustainable Waste Management Systems. Journal of Cleaner Production, 18, 1639-1651. http://dx.doi.org/10.1016/j.jclepro.2010.07.009

[14] United Nations Terminology (2013) Waste Hierachy. http://unterm.un.org/DGAACS/unterm.nsf/0f99a7d734f48ac385256a07005e48fb/8d453dd6188c26c185257b1f006c44f $\underline{\mathrm{b}}$

[15] Vasiljević, T.Z., Srdjević, Z., Bajčetić, R. and Miloradov, M.V. (2012) GIS and the Analytic Hierarchy Process for Regional Landfill Site Selection in Transitional Countries: A Case Study from Serbia. Environmental Management, 49, 445-458. http://dx.doi.org/10.1007/s00267-011-9792-3

[16] Lancellotti, I., Kamseu, E., Michelazzi, M., Barbieri, L., Corradi, A. and Leonelli, C. (2010) Chemical Stability of Geopolymers Containing Municipal Solid Waste Incinerator Fly Ash. Waste Management, 30, 673-679. http://dx.doi.org/10.1016/j.wasman.2009.09.032

[17] European Commission, EC (2008) http://ec.europa.eu/environment/waste/framework/pdf/guidance_doc.pdf.

[18] Bulkeley, H. and Gregson, N. (2009) Crossing the Threshold: Municipal Waste Policy and Household Waste Generation. Environment and Planning A, 41, 929-945. http://dx.doi.org/10.1068/a40261 
[19] Geocycle (2011) The Waste Management Hierarchy. http://www.geocycle.ph/en/lets-get-started/the-waste-management-heirarchy.html

[20] Manfredi, S., Tonini, D., Christensen, T.H. and Scharff, H. (2009) Landfilling of Waste: Accounting of Greenhouse Gases and Global Warming Contributions. Waste Management \& Research, 27, 825-836. http://dx.doi.org/10.1177/0734242X09348529

[21] Department of Sport and Recreation (2011) Sustainability Pack. http://www.dsr.wa.gov.au/sustainability-pack-1

[22] Collins, A. and Flynn, A. (2008) Measuring the Environmental Sustainability of a Major Sporting Event: A Case Study of the FA Cup Final. Tourism Economics, 14, 751-768. http://dx.doi.org/10.5367/000000008786440120

[23] Veolia (2012) Wembley, Wembley, Greenest Ever Cup Final at Wembley. http://www.veoliaenvironmentalservices.co.uk/Main/Media-centre/Press-releases/Wembley-Wembley-Greenest-EverCup-Final-At-Wembley

[24] Veolia (2013) Wembley Scores on Waste Recycling. http://www.veoliaenvironmentalservices.co.uk/London/About-us/News/Press-releases/Wembley-Scores-on-Recycling

[25] Coetzee, B. and Jenkin, T. (2010) Cape Town’s 2010 Waste Management Plans: Solid Waste. Resource, 12, 16-21.

[26] United Nations Environmental Programme (2008) United Nations Environment Programme. Beijing 2008 Olympic Games: An Environmental Review. http://www.unep.org/pdf/BEIJING_REPORT_COMPLETE.pdf

[27] Inside The Game (2013) The Final Chapter on a Sustainable London 2012. http://www.insidethegames.biz/sustainability/1012222-the-final-chapter-on-a-sustainable-london-2012

[28] Girginov, V. (2012) Handbook of the London 2012 Olympic and Paralympic Games: Volume One: Making the Games. Routledge.

[29] The Football Association (2012) The Football Structure. http://www.thefa.com/ /media/files/word/fa-student-research-resource.ashx/FA-Student-Research-Resource.doc

[30] Football Pyramid (2012) Football Pyramid Statistics. http://thepyramid.info/stats/stats.htm\#lpl

[31] Arsenal Football Club (2014) Environment and Regeneration. http://www.arsenal.com/the-club/community/environment-and-regeneration.\#sthash.N5NPhu6a.dpuf

[32] Manchester City Football Club (2013) Manchester City Annual Report 2012-13 [Online]. http://content.mcfc.co.uk/ /media/Files/Annual Report/MCFC AR.pdf

[33] Manchester United Football Club (2011) Community and Environmental Sustainability [Online]. http://www.manutd.com/ /media/Files/PDF/ClubCharter/2011/community and environmental sustainability.ashx

[34] Kolyperas, D. (2012) Corporate and Social Responsibility in Professional Football Club Organizations. University of Stirling, Stirling.

[35] Dickson, C. and Arcodia, C. (2010) Promoting Sustainable Event Practice: The Role of Professional Associations. International Journal of Hospitality Management, 29, 236-244. http://dx.doi.org/10.1016/j.ijhm.2009.10.013

[36] Mallen, C., Stevens, J., Adams, L. and McRoberts, S. (2010) The Assessment of the Environmental Performance of an International Multi-Sport Event. European Sport Management Quarterly, 10, 97-122. http://dx.doi.org/10.1080/16184740903460488

[37] Football Insights (2007) Football League Tiers in England. http://footballinsights.wordpress.com/2007/08/17/11-tiers-of-english-football/

[38] DEFRA (2013) Department for Environment, Food \& Rural Affairs 2012 Greenhouse Gas Conversion Factors. http://www.gov.uk/government/publications/2012-greenhouse-gas-conversion-factors-for-company-reporting

[39] Larsen, H.N., Pettersen, J., Solli, C. and Hertwich, E.G. (2013) Investigating the Carbon Footprint of a University-The Case of NTNU. Journal of Cleaner Production, 48, 39-47. http://dx.doi.org/10.1016/j.jclepro.2011.10.007

[40] Townsend, J. and Barrett, J. (2013) Exploring the Applications of Carbon Footprinting towards Sustainability at a UK University: Reporting and Decision Making. Journal of Cleaner Production, in Press. http://dx.doi.org/10.1016/j.jclepro.2013.11.004

[41] Ozawa-Meida, L., Brockway, P., Letten, K., Davies, J. and Fleming, P. (2013) Measuring Carbon Performance in a UK University through a Consumption-Based Carbon Footprint: De Montfort University Case Study. Journal of Cleaner Production, 56, 185-198. http://dx.doi.org/10.1016/j.jclepro.2011.09.028

[42] Isthmian League (2013) http://www.isthmian.co.uk/archive-1355/

[43] East Midlands Football (2013) League Attendance Figures 2012/13. http://www.emfootball.co.uk/attend2013.html

[44] Non League Matters (2013) Attendance Essex Senior League 2012/13. http://www.nonleaguematters.co.uk/divisions/26/2/ 
[45] Office of National Statistics (2014) Measuring National Wellbeing in UK. http://www.ons.gov.uk/ons/rel/wellbeing/measuring-national-well-being/life-in-the-uk--2014/art-mnwb--life-in-the-uk-2014.html?format=print

[46] Morrissey, A.J. and Phillips, P.S. (2007) Biodegradable Municipal Waste (BMW) Management Strategy in Ireland: A Comparison with Some Key Issues in the BMW Strategy Being Adopted in England. Resources, Conservation and Recycling, 49, 353-371. http://dx.doi.org/10.1016/j.resconrec.2006.05.002

[47] Emery, A., Davies, A., Griffiths, A. and Williams, K. (2007) Environmental and Economic Modelling: A Case Study of Municipal Solid Waste Management Scenarios in Wales. Resources, Conservation and Recycling, 49, $244-263$. http://dx.doi.org/10.1016/j.resconrec.2006.03.016

[48] Watson, G. and Powrie, W. (2014) Re-Engineering the City for Sustainable Solid Waste Resource Management. In: Dixon, T., Eames, M., Hunt, M. and Lannon, S., Eds., Urban Retrofitting for Sustainability: Mapping the Transition to 2050, Routledge, London, 233.

[49] Dahlén, L. and Lagerkvist, A. (2010) Pay as You Throw: Strengths and Weaknesses of Weight-Based Billing in Household Waste Collection Systems in Sweden. Waste Management, 30, 23-31. http://dx.doi.org/10.1016/j.wasman.2009.09.022

[50] Akansel, B., Ates, E., Tapan, P. and Özden, Y. (2010) Implementation of CSR at European Football Clubs. FIFA/CIES Programme in Sport Management, Bahçeşehir University, İstanbul.

[51] Levermore, R. (2010) CSR for Development through Sport: Examining Its Potential and Limitations. Third World Quarterly, 31, 223-241. http://dx.doi.org/10.1080/01436591003711967

[52] Hamil, S., Walters, G. and Watson, L. (2010) The Model of Governance at FC Barcelona: Balancing Member Democracy, commercial Strategy, Corporate Social Responsibility and Sporting Performance. Soccer \& Society, 11, 475-504. http://dx.doi.org/10.1080/14660971003780446

[53] Walters, G. and Chadwick, S. (2009) Corporate Citizenship in Football: Delivering Strategic Benefits through Stakeholder Engagement. Management Decision, 47, 51-66. http://dx.doi.org/10.1108/00251740910929696

[54] Anagnostopoulos, C. (2011) From Corporate Social Responsibility (CSR) to Club Stakeholder Relationship (CSR): The Case of Football. The Social Responsibility Research Network Constitution, No. 3, 14-17. http://www.socialresponsibility.biz/2011-3.pdf\#page=14

[55] Blumrodt, J., Desbordes, M. and Bodin, D. (2013) Professional Football Clubs and Corporate Social Responsibility. Sport, Business and Management: An International Journal, 3, 205-225. http://dx.doi.org/10.1108/SBM-04-2011-0050

[56] Babiak, K. and Wolfe, R. (2006) More Than Just a Game? Corporate Social Responsibility and Super Bowl XL. Sport Marketing Quarterly, 15, 214.

[57] Kuhn, T., Pittel, K. and Schulz, T. (2003) Recycling for Sustainability—A Long Run Perspective? International Journal of Global Environmental Issues, 3, 339-355.

[58] Center for International and European Studies (2010) Implementation of CSR at European Football Clubs. http://www.cies-uni.org/sites/default/files/BU_implementation_of_csr_at_european_football_clubs.pdf

[59] Panton, M. (2012) Football and Corporate Social Responsibility. Birkbeck Sport Business Centre, 5, No. 2. 
Scientific Research Publishing (SCIRP) is one of the largest Open Access journal publishers. It is currently publishing more than 200 open access, online, peer-reviewed journals covering a wide range of academic disciplines. SCIRP serves the worldwide academic communities and contributes to the progress and application of science with its publication.

Other selected journals from SCIRP are listed as below. Submit your manuscript to us via either submit@scirp.org or Online Submission Portal.
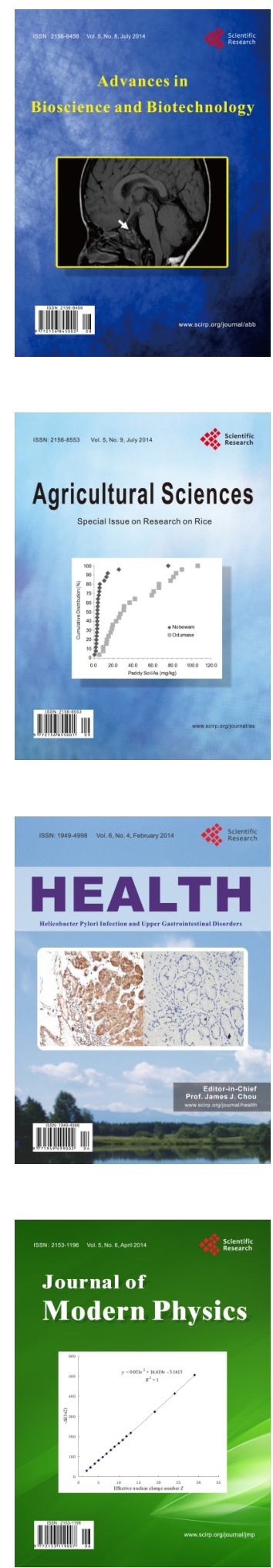
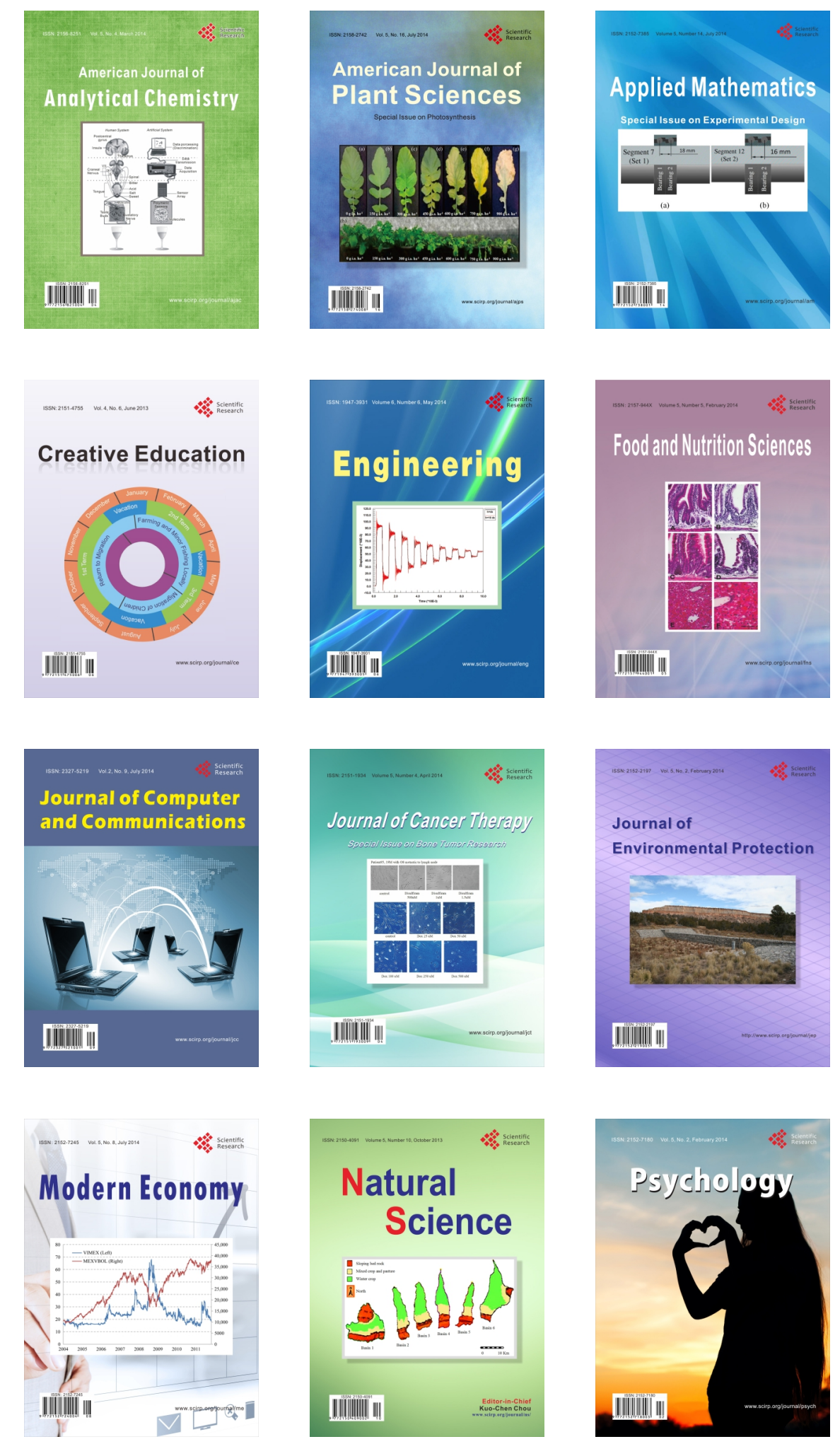